\title{
Foreword
}

\section{THE OSGOODE SOCIETY}

The purpose of The Osgoode Society is to encourage research and writing in the history of Canadian law. The Society, which was incorporated in 1979 and is registered as a charity, was founded at the initiative of the Honourable R. Roy McMurtry, former attorney general for Ontario, and officials of the Law Society of Upper Canada. Its efforts to stimulate the study of legal history in Canada include a research support program, a graduate-student research assistance program, and work in the fields of oral history and legal archives. The Society publishes (at the rate of about one a year) volumes of interest to the Society's members that contribute to legal-historical scholarship in Canada, including studies of the courts, the judiciary, and the legal profession; biographies; collections of documents; studies in criminology and penology; accounts of great trials; and works in the social and economic history of the law.

Current directors of The Osgoode Society are Jane Banfield, Marion Boyd, Brian Bucknall, Archie Campbell, J. Douglas Ewart, Martin Friedland, John Honsberger, Kenneth Jarvis, Allen Linden, Colin McKinnon, Roy McMurtry, Brendan O'Brien, Peter Oliver, Allan Rock, James Spence, and Richard Tinsley. The annual report and information about membership may be obtained by writing to: The Osgoode Society, Osgoode Hall, 130 Queen Street West, Toronto, Ontario, Canada, M5H 2N6. Members receive the annual volumes published by the Society.

The directors of The Osgoode Society are pleased to be cooperating with the Canadian Association of Chiefs of Police in the publication of 
Policing Canada's Century: A History of the Canadian Association of Chiefs of Police. This work was commissioned by the CACP, and Professor Marquis's research has been supported by that organization.

The resulting publication is significant in several respects. For The Osgoode Society, it is a departure into a relatively new and rapidly developing field of study. Canadian historians have generally ignored their police history. The Canadian Association of Chiefs of Police is an important but little known organization whose development is a crucial part of the history of Canadian policing. Its history, as Professor Marquis amply demonstrates, is rich in personalities, controversies, and issues; and its story offers vital insights into the social and intellectual history of policing in twentieth-century Canada. The perspective adopted in Professor Marquis's book is from the top down, tracing the concerns of senior police officials, their relationships with all levels of government and their efforts to understand, and at times to shape, public opinion as it touched upon issues of policy. In writing the history of the Canadian Association of Chiefs of Police, Professor Marquis takes a broad view and by throwing much light on numerous policing issues lays the indispensable groundwork for future studies of policing in Canada.

R. Roy McMurtry

President

Peter N. Oliver

Editor-in-Chief 